\title{
Comparative Efficacy of Intrathecal Pethidine with Lignocaine 5\% (Heavy) as Sole Anaesthetic Agent for Perineal Operations
}

\author{
Jitta Sudershan Reddy ${ }^{1}$ \\ ${ }^{1}$ Associate Professor, Department of Anaesthesiology, Prathima Medical College, Karimnagar, Telangana, India.
}

\section{Abstract}

Background: The discovery of opioid receptors and ligand in the brain and spinal cord lead to the feasibility of their use intrathecally. Pethidine is the only narcotic that has been shown to be effective intrathecally for surgery. This is probably because it as a phenyl-piperidine derivative and has a structure and action similar to that of local anaesthetic. Subjects and Methods: 50 patients belonging to ASA grade 1 and 2 physical status were randomly assigned to two groups A and B. Patients in group A received $1 \mathrm{ml}$ of $5 \%$ lignocaine (heavy) intrathecally and those in group B gained intrathecal Pethidine (preservative-free) $0.5 \mathrm{mg} / \mathrm{kg}$ body weight. The time for onset and level of sensory blockade, onset and degree of motor blockade, hemodynamic parameters, time for regression of sensory and motor blockade, duration of postoperative analgesia and side effects were noted and compared in both the groups. Results: Two groups were comparable with respect to age, sex, height and weight. The onset of sensory and motor blockade in-group A was $2.00 \pm 1.06 \mathrm{~min}$ and $2.56 \pm 0.88$ and in-group B it was $3.56 \pm 1.64$ min and $7.22 \pm 1.11$ min respectively, which was statistically significant. Grade I motor paralysis was seen in 2 cases (10\%) in group A and 15 cases (75\%) in group B. Grade II motor paralysis was seen in 6 cases (30\%) in group A and 5 cases (25\%) in group B. Grade III motor paralysis was viewed in 12 cases $(60 \%)$ in group A and 0 cases $(0 \%)$ in group B. Grade I and III motor paralysis in the groups were statistically significant ( $\mathrm{p}<0.05$ ). Time for sensory regression at L1 was $65.12 \pm 4.83$ min in-group A and $94.60 \pm 6.88$ min in-group B that was statistically very significant $(\mathrm{p}<0.05)$. The time for regression of motor blockade was $60.40 \pm 3.85$ in-group A and $60.20 \pm 5.02$ in group B, which was statistically not significant ( $>0.05)$. The duration of postoperative analgesia was $122.84 \pm 9.37$ min in-group A and $320.60 \pm 23.02$ in group B, which was statistically very significant. The incidence of side effects was comparable in both groups. Conclusion: Pethidine (preservative-free) $0.5 \mathrm{mg} / \mathrm{kg}$ body weight can be used intrathecally as a sole anaesthetic agent to provide prolonged postoperative analgesia associated with hemodynamic stability and early ambulation in patients undergoing perineal surgeries.

Keywords: Saddle block, Pethidine, Lignocaine, Blood Pressure, Sensory blockade, Motor blockade, Postoperative analgesia.

Corresponding Author: Dr. Jitta Sudershan Reddy, Associate Professor, Department of Anaesthesiology, Prathima Medical College, Karimnagar, Telangana, India.

Email: jaffarshaik4407@gmail.com

Received: May 2020

Accepted: May 2020

\section{Introduction}

Pain is defined, according to the International Association for the study of pain, as "an unpleasant, sensory and emotional experience associated with actual or potential tissue damage or described in terms of such damage."

The role of an anesthesiologist is to render the patient pain free during surgical procedures. However, patient's problems with anxiety do not end with surgical procedures. Pain during the postoperative period is a cause of concern not only for the patient but also for the surgeon and anesthesiologist.

Perineal surgeries usually are limited to the area of innervation of sacral fibers and relaxation of the abdominal musculature is not a necessity. The so-called "Saddle block" anesthesia limits blockade to sacral fibers and carry the advantages of minimal hemodynamic and respiratory disturbance. Spinal anaesthesia with lignocaine as 5\% hyperbaric solution is famous for brief surgical procedures due to the rapid regression of sensory and motor block. ${ }^{[1]}$

Inadequate pain relief in the perineal region is discomforting to the patient and can cause reflex inhibition of bladder evacuation. ${ }^{[3]}$ Since perineal surgeries do not require extensive motor blockade with muscle relaxation, avoiding local anaesthetic and using intrathecal Pethidine alone has been associated with hemodynamic stability and early ambulation. Pethidine acts on the opioid receptors in the spinal cord and by itself has got local anaesthetic activity. Pethidine in a dose of $0.5 \mathrm{mg} / \mathrm{kg}$ body weight was found to produce a long duration of sensory blockade compared to lignocaine $5 \%$ (heavy) alone given intrathecally. ${ }^{[2-5]}$ Hence, this study is designed for analyzing intrathecal Pethidine with lignocaine (heavy) $5 \%$ for perineal operations as a sole anaesthetic agent.

The aim of the study is to Evaluate and compare intrathecal pethidine $0.5 \mathrm{mg} / \mathrm{kg}$ and $5 \%$ lignocaine (heavy) for patients posted for perineal operations with respect to:

- Onset and level of sensory blockade 
- Onset and degree of motor blockade

- Hemodynamic parameters.

- The time required for motor recovery

- The time necessary for sensory regression

- Duration of postoperative analgesia.

- Side effects, if any.

B. To study the outcome of comparative study.

\section{Subjects and Methods}

A prospective clinical study was conducted on patients coming for elective perineal surgeries in Vijayanagara Institute of Medical Sciences, Bellary for the period of one year from 1-01-2019 to 1-11-2019 after obtaining permission from the institutional ethics committee.

Informed consent was obtained from all patients, 50 patients aged between 20 to 45 years of either sex belonging to ASA grade I or II physical status were randomly allocated into two groups- Group A and Group B, each consisting of 25 patients.

- Patients in Group A received $1 \mathrm{ml}$ of 5\%lignocaine (heavy)

- Patients in Group B received pethidine $0.5 \mathrm{mg} / \mathrm{kg}$ of $5 \%$ (preservative-free) pethidine intrathecally.

\section{Inclusion criteria}

a. Elective general surgical/ urological/ gynecological patients scheduled to undergo perineal surgeries.

b. Patients belonging to ASA I or II

c. Patients of either sex aged between 20 and 45 years.

\section{Exclusion criteria}

a. Patients refusal for Spinal anaesthesia

b. Patients belonging to ASA grade III or IV

c. Age group less than 20 years and more than 45 years.

d. Patients with a history of allergies/ hypersensitive to multiple drugs or local anaesthetics.

e. All contraindications for spinal anaesthesia

\section{Protocol}

Informed and written consent was obtained from the patient or patient attenders. Routine investigations that included Blood investigations: $\mathrm{Hb} \% \mathrm{BT}, \mathrm{CT}$, Blood grouping and $\mathrm{Rh}$ typing, Blood sugar, blood urea, Serum creatinine and Urine routine were carried out.

The patient's height and weight were also recorded prior to surgery.

All patients were premedicated with Injection Ranitidine $50 \mathrm{mg}$ I.V and Injection Metoclopramide 10mg I.V 30 minutes before surgery

The patient was shifted to the operation theater and intravenous access established and preloaded with $500 \mathrm{ml}$ of Ringer Lactate. Monitors were then connected, which included pulse oximeter, noninvasive blood pressure and ECG.

Basal parameters including blood pressure, pulse rate and $\mathrm{SpO} 2$ were recorded. With the patients in sitting position, under aseptic precautions, the back was painted and draped, the dural puncture was performed at the L3-L4 or L4-L5 intervertebral space using 25 spinal gauze needle after infiltration with local anaesthesia.
Patients in group A $(n=20)$ received $1 \mathrm{ml}$ of $5 \%$ lignocaine (heavy) and those in Group $\mathrm{B}(\mathrm{n}=20)$ received $5 \%$ preservative-free pethidine, $0.5 \mathrm{mg} / \mathrm{kg}(0.01 \mathrm{ml} / \mathrm{kg}$ body weight) injected intrathecally over $4-5 \mathrm{sec}$. The patient was kept in the sitting position for 5 minutes and then laid in a supine position.

The following parameters were monitored.

1. Sensory blockade ${ }^{[9]}$

- Onset of sensory blockade: is analgesia to pinprick at L1

- A peak level of neural blockade: is the maximum height of analgesia to pinprick reached during the study period.

- Duration of sensory block: from the time of onset of sensory block to the time when patient first complains of pain at the site of surgery.

\section{Motor blockade ${ }^{[9]}$}

Onset of motor block: Time from an injection of test drug to the time when grade I motor blockade was reached. (Patients were asked to lift their legs, time when heaviness or difficulty in raising the legs was taken as the time of onset of motor block.)

Duration of motor block: The time from onset of a motor block to the time when grade 0 motor recovery takes place. Ability to lift the extended leg was taken as recovery from motor paralysis.

Motor block was assessed using a modified Bromage scale. Free movement of legs feet with the ability to raise extended legs

I. Inability to raise the extended leg, knee flexion is decreased, but full flexion of feet and ankle is present.

II. Inability to raise legs or flex knees, flexion of ankle and feet present. III: Inability to raise legs, flex knee, ankle or move toes (complete block)

\section{Duration of postoperative analgesia according to} Rawal, sjostrand and Dahlstorm (1981).

The time between the intrathecal injection of Pethidine and the time pain becomes severe enough to require additional analgesia.

Postoperative pain was assessed hourly.

The duration and quality of postoperative analgesia were assessed by the patients and ward nurses.

\section{Hemodynamic parameters}

Blood Pressure and pulse rate were recorded once in two minutes for the first ten minutes, once in five minutes for the next thirty minutes and every ten minutes thereafter till the end of the surgery.

Bradycardia was defined as a pulse rate of less than $60 / \mathrm{min}$ and was treated with $0.6 \mathrm{mg}$ of injection Atropine I.V

Hypotension was defined as a fall of systolic BP > 30\% of pre block values and was treated with rapid infusion of IV fluids and oxygen supplementation by face mask and foot end elevation was given as necessary and later by using vasopressor, inj. Mephentermine $6 \mathrm{mg}$ I.V in incremental doses (if above measures failed).

Side effects/complications, if any were noted Sedation score:

O: Fully awake

1: Drowsy

2: Sedated but arousable to verbal commands. 
3: Sedated but arousable to painful stimuli

4: Deeply sedated, not arousable to oral or painful stimuli.

Respiratory depression was defined as respiratory rate $<9$ breaths/min or SPO2 $<90 \%$ and it was treated by administering 4 liters of oxygen per min with a face mask.

Pruritus: was assessed as:

- Mild: Itching is a minor concern.

- Moderate: Itching is a primary concern, although bearable.

- Severe: Unbearable patient requested treatment.

Statistical Methods:

The student t-test/Chi-square test has been used to find the significance of homogeneity of study characteristics between two groups of patients. Student t-test (Unpaired, two-tailed) has been used to find the significance of hemodynamics between two groups.

\section{Results}

In our study 40 patients were randomly divided and allocated to two groups of 25 each, Group A patients received intrathecal Lignocaine 5\% (heavy) $1 \mathrm{ml}$ and patients in Group B received intrathecal Pethidine $0.5 \mathrm{mg} / \mathrm{kg}$ body weight.

The following were the observations and results in the two groups.

\section{Table 1: Patient characteristics}

\begin{tabular}{|l|l|l|l|}
\hline $\begin{array}{l}\text { Basic } \\
\text { characteristics }\end{array}$ & Group A & Group B & p-value \\
\hline Age in years & $32.80 \pm 7.48$ & $31.68 \pm 7.59$ & 0.602 \\
\hline Height in cm & $165.44 \pm 7.35$ & $167.72 \pm 7.48$ & 0.282 \\
\hline Weight in kg & $57.32 \pm 6.04$ & $58.68 \pm 6.36$ & 0.442 \\
\hline Sex (Male :Female) & $19: 6$ & $18: 7$ & 0.747 \\
\hline
\end{tabular}

Patients in both groups are statistically similar on the basis of age, sex, height and weight. The mean age in group A was 32.80 years (SD7.48) and in group B 31. years (SD 7.59), which is not statistically significant $(p>0.05)$ and hence comparable.

The mean height in group A was $165.44 \mathrm{cms}$ (SD7.35) and in group B $167.72 \mathrm{cms}$ (SD 7.48 ), which is not statistically significant $(\mathrm{p}>0.05)$. The mean weight in group A was 57.32 $\mathrm{kg}$ (SD 6.04) and in group B $58.68 \mathrm{~kg}$ (SD 6.36), which is not statistically significant $(\mathrm{p}>0.05)$.

Table 2: Comparison of Study parameters between the two groups

\begin{tabular}{|l|l|l|l|}
\hline Study parameters & Group A & Group B & p-value \\
\hline $\begin{array}{l}\text { Onset of Sensory Block } \\
\text { (min) }\end{array}$ & $2.00 \pm 1.06$ & $6.56 \pm 1.64$ & $<0.001^{* *}$ \\
\hline $\begin{array}{l}\text { Onset of motor block } \\
\text { (min) }\end{array}$ & $2.56 \pm 0.88$ & $7.22 \pm 1.11$ & $<0.001^{* *}$ \\
\hline $\begin{array}{l}\text { Time required for motor } \\
\text { recovery (min) }\end{array}$ & $63.40 \pm 3.85$ & $64.20 \pm 5.02$ & 0.875 \\
\hline $\begin{array}{l}\text { Time required for sensory } \\
\text { regression (min) }\end{array}$ & $67.12 \pm 4.83$ & $98.60 \pm 6.88$ & $<0.001^{* *}$ \\
\hline $\begin{array}{l}\text { Duration of postoperative } \\
\text { analgesia (min) }\end{array}$ & $120.84 \pm 9.37$ & $320.60 \pm 23.02$ & $<0.001^{* *}$ \\
\hline
\end{tabular}

The mean duration of onset of sensory blockade in-group A was 2.00 (SD 1.06) and in-group B 6.56 (SD 1.64), which is statistically significant $(\mathrm{p}<0.05)$. The mean duration of onset of motor blockade in-group A was 2.56 (SD 0.88) and in group B 7.22 (SD 1.11), which is statistically significant $(\mathrm{p}<0.05)$.

Table 3: Comparison of the degree of motor blockade (DMB)

\begin{tabular}{|c|c|c|c|c|c|}
\hline \multirow[t]{2}{*}{$\begin{array}{l}\text { Motor } \\
\text { Blockade }\end{array}$} & \multicolumn{2}{|c|}{ Group A $(n=20)$} & \multicolumn{2}{|c|}{$\begin{array}{l}\text { Group } \\
(\mathbf{n}=\mathbf{2 0})\end{array}$} & \multirow[t]{2}{*}{ p-value } \\
\hline & No & $\%$ & No & $\%$ & \\
\hline I & 2 & 10.0 & 15 & 75.0 & $<0.001$ ** \\
\hline II & 6 & 30.0 & 5 & 25.0 & 1.000 \\
\hline III & 12 & 60.0 & - & - & $<0.001 * *$ \\
\hline
\end{tabular}

The comparison of mean DMB between two groups is statistically significant $(\mathrm{p}<0.05)$ in Grade 1 and 3 but statistically not significant ( $\mathrm{p}>0.05)$ in Grade 2.

Table 4: Comparison of Sensory levels between the two groups

\begin{tabular}{|l|l|l|l|l|l|}
\hline \multirow{2}{*}{ Sensory levels } & \multicolumn{2}{|l|}{ Group A (n=20) } & \multicolumn{2}{|l|}{$\begin{array}{l}\text { Group } \\
(\mathbf{n = 2 5})\end{array}$} & \multirow{2}{*}{ p-value } \\
\cline { 2 - 5 } & No & \% & No & \% & \\
\hline$\Lambda 1$ & 2 & 10 & 15 & 75.0 & $<0.001 * *$ \\
\hline T6 & 2 & 10 & - & - & 0.490 \\
\hline T9 & 4 & 20.0 & - & - & $0.022 * *$ \\
\hline T10 & 8 & 40.0 & 1 & 5.0 & $0.002 * *$ \\
\hline T11 & 4 & 20.0 & 1 & 5.0 & 0.189 \\
\hline T12 & - & - & 3 & 15.0 & 0.110 \\
\hline
\end{tabular}

\begin{tabular}{|c|c|c|c|c|c|}
\hline \multirow{3}{*}{$\begin{array}{l}\text { Study } \\
\text { Period }\end{array}$} & \multicolumn{4}{|c|}{ Pulse rate (bpm) } & \multirow{3}{*}{ P-value } \\
\hline & \multicolumn{2}{|c|}{ Group A } & \multicolumn{2}{|c|}{ Group B } & \\
\hline & Mean & SD & Mean & SD & \\
\hline Baseline & 75.32 & 5.91 & 77.60 & 6.45 & 0.199 \\
\hline SAB & 75.84 & 5.34 & 79.16 & 6.39 & 0.052 \\
\hline $2 \min$ & 76.84 & 5.15 & 80.12 & 6.26 & 0.051 \\
\hline $4 \min$ & 76.72 & 5.81 & 80.00 & 6.83 & 0.073 \\
\hline $6 \mathrm{~min}$ & 77.32 & 5.97 & 79.92 & 6.81 & 0.155 \\
\hline $8 \min$ & 78.12 & 6.52 & 80.68 & 7.11 & 0.191 \\
\hline $10 \mathrm{~min}$ & 77.92 & 6.63 & 80.20 & 7.80 & 0.271 \\
\hline $15 \mathrm{~min}$ & 77.04 & 7.13 & 79.84 & 8.47 & 0.212 \\
\hline $20 \mathrm{~min}$ & 76.44 & 5.78 & 77.64 & 6.58 & 0.496 \\
\hline $25 \mathrm{~min}$ & 76.84 & 5.34 & 79.16 & 6.39 & 0.052 \\
\hline $30 \mathrm{~min}$ & 76.84 & 5.15 & 80.12 & 6.26 & 0.051 \\
\hline $35 \mathrm{~min}$ & 78.12 & 6.52 & 80.16 & 7.24 & 0.050 \\
\hline $40 \mathrm{~min}$ & 77.32 & 5.97 & 79.92 & 6.81 & 0.155 \\
\hline $50 \mathrm{~min}$ & 78.12 & 6.52 & 79.16 & 6.39 & 0.271 \\
\hline $60 \mathrm{~min}$ & 76.72 & 5.81 & 77.64 & 6.58 & 0.496 \\
\hline $70 \mathrm{~min}$ & 75.32 & 5.91 & 77.60 & 6.45 & 0.199 \\
\hline
\end{tabular}

Table 6: b Comparison of systolic blood pressure ( $\mathrm{mmHg}$ ) between two groups

\begin{tabular}{|l|l|l|l|l|l|}
\hline \multirow{2}{*}{$\begin{array}{l}\text { Study } \\
\text { Period }\end{array}$} & \multicolumn{3}{|l|}{ Systolic BP $(\mathbf{m m H g}$ ) } & \multirow{2}{*}{ p-value } \\
\cline { 2 - 5 } & \multicolumn{2}{|c|}{ Group A } & \multicolumn{2}{c|}{ Group B } & \\
\cline { 2 - 5 } & Mean & SD & Mean & SD & \\
\hline Baseline & 118.64 & 6.22 & 119.80 & 5.00 & 0.471 \\
\hline SAB & 119.04 & 6.15 & 122.44 & 16.89 & 0.349 \\
\hline $2 \mathrm{~min}$ & 119.92 & 4.12 & 120.84 & 4.11 & 0.438 \\
\hline $4 \mathrm{~min}$ & 117.40 & 8.84 & 118.92 & 5.47 & 0.468 \\
\hline $6 \mathrm{~min}$ & 115.64 & 13.09 & 119.80 & 5.42 & 0.149 \\
\hline $8 \mathrm{~min}$ & 116.12 & 11.60 & 119.88 & 5.87 & 0.155 \\
\hline $10 \mathrm{~min}$ & 118.00 & 9.78 & 120.36 & 5.43 & 0.273 \\
\hline $15 \mathrm{~min}$ & 118.04 & 6.50 & 120.16 & 5.02 & 0.203 \\
\hline $20 \mathrm{~min}$ & 118.96 & 5.68 & 120.64 & 4.47 & 0.251 \\
\hline $25 \mathrm{~min}$ & 119.48 & 5.58 & 120.80 & 4.88 & 0.378 \\
\hline $30 \mathrm{~min}$ & 119.88 & 6.17 & 121.32 & 4.98 & 0.369 \\
\hline $35 \mathrm{~min}$ & 120.64 & 5.33 & 121.80 & 4.42 & 0.406 \\
\hline $40 \mathrm{~min}$ & 121.52 & 5.16 & 122.20 & 3.86 & 0.600 \\
\hline $50 \mathrm{~min}$ & 120.56 & 5.12 & 121.12 & 5.09 & 0.700 \\
\hline $60 \mathrm{~min}$ & 120.64 & 4.31 & 120.72 & 4.34 & 0.948 \\
\hline $70 \mathrm{~min}$ & 120.48 & 4.93 & 120.88 & 4.01 & 0.754 \\
\hline
\end{tabular}


The comparison of the mean sensory level reached between two groups is statistically significant $(\mathrm{p}<0.05)$ at $\mathrm{L} 1, \mathrm{~T} 9$ and T10 levels. But not at T6, T11 and T12 levels.

The mean time for motor recovery in-group A was 60.40 (SD 3.85) min and in-group B 60.20 (SD 5.02) min, which is statistically not significant $(\mathrm{p}>0.05)$. The mean time for sensory regression in-group A was 65.12 (SD 4.83) min and in-group B 94.60 (SD 6.88) min, which is statistically significant $(\mathrm{p}<0.05)$.

The mean duration of postoperative analgesia in-group A was 122.84 (SD 9.37) $\mathrm{min}$ and in group B 320.60 (SD 23.02) min, which is statistically significant $(\mathrm{p}<0.05)$. [Table 4]

The comparison of pulse rate between the two groups is statistically not meaningful ( $p>0.05$ ). No incidences of bradycardia were recorded. [Table 5]

The correlation of systolic blood pressure between the two groups is statistically not significant ( $p>0.05)$.

\section{Table 7: Comparison of diastolic blood pressure $(\mathrm{mmHg})$} between two groups

\begin{tabular}{|l|l|l|l|l|l|}
\hline \multirow{2}{*}{$\begin{array}{l}\text { Study } \\
\text { Period }\end{array}$} & \multicolumn{3}{|l|}{ Diastolic BP $(\mathbf{m m H g})$} & \multirow{2}{*}{ P-value } \\
\cline { 2 - 5 } & \multicolumn{2}{|l|}{ Group A } & Group B & \\
\cline { 2 - 5 } & Mean & SD & Mean & SD & \\
\hline Baseline & 75.72 & 4.70 & 75.68 & 3.50 & 0.973 \\
\hline SAB & 74.40 & 3.42 & 76.32 & 3.35 & 0.873 \\
\hline $2 \mathrm{~min}$ & 75.44 & 3.18 & 76.24 & 3.56 & 0.406 \\
\hline $4 \mathrm{~min}$ & 73.20 & 3.35 & 75.04 & 4.93 & 0.723 \\
\hline $6 \mathrm{~min}$ & 75.72 & 4.70 & 75.68 & 3.50 & 0.973 \\
\hline $8 \mathrm{~min}$ & 74.52 & 2.80 & 75.52 & 14.65 & 0.611 \\
\hline $10 \mathrm{~min}$ & 75.52 & 2.02 & 77.56 & 4.71 & 0.315 \\
\hline $15 \mathrm{~min}$ & 74.52 & 2.80 & 75.28 & 4.83 & 0.499 \\
\hline $20 \mathrm{~min}$ & 72.72 & 1.81 & 74.00 & 14.78 & 0.669 \\
\hline $25 \mathrm{~min}$ & 74.52 & 2.80 & 75.52 & 14.65 & 0.411 \\
\hline $30 \mathrm{~min}$ & 75.72 & 4.70 & 75.68 & 3.50 & 0.893 \\
\hline $35 \mathrm{~min}$ & 74.52 & 2.80 & 75.28 & 4.83 & 0.499 \\
\hline $40 \mathrm{~min}$ & 75.52 & 2.02 & 76.56 & 4.71 & 0.315 \\
\hline $50 \mathrm{~min}$ & 74.52 & 2.80 & 75.28 & 4.83 & 0.499 \\
\hline $60 \mathrm{~min}$ & 74.64 & 2.56 & 74.04 & 14.47 & 0.839 \\
\hline $70 \mathrm{~min}$ & 75.72 & 4.70 & 75.68 & 3.50 & 0.973 \\
\hline
\end{tabular}

The comparison of diastolic blood pressure between the two groups is statistically not significant ( $p>0.05)$.

Table 8: Comparison of $\mathrm{SpO2}(\%)$ between two groups

\begin{tabular}{|c|c|c|c|c|c|}
\hline \multirow{3}{*}{$\begin{array}{l}\text { Study } \\
\text { Period }\end{array}$} & \multicolumn{4}{|c|}{ SpO2 (\%) } & \multirow[t]{3}{*}{ p-value } \\
\hline & \multicolumn{2}{|c|}{ Group A } & \multicolumn{2}{|c|}{ Group B } & \\
\hline & Mean & SD & Mean & SD & \\
\hline Baseline & 99 & 0.01 & 100 & 0.01 & 0.499 \\
\hline SAB & 99 & 0.00 & 99 & 0.01 & 0.119 \\
\hline $2 \min$ & 99 & 0.01 & 99 & 0.01 & 0.637 \\
\hline $4 \min$ & 99 & 0.01 & 99 & 0.01 & 0.674 \\
\hline $6 \min$ & 99 & 0.01 & 99 & 0.01 & 0.703 \\
\hline $8 \mathrm{~min}$ & 99 & 0.01 & 99 & 0.01 & 0.405 \\
\hline $10 \mathrm{~min}$ & 99 & 0.01 & 99 & 0.01 & 0.087 \\
\hline $15 \mathrm{~min}$ & 99 & 0.01 & 99 & 0.01 & 0.074 \\
\hline $20 \mathrm{~min}$ & 98 & 0.10 & 99 & 0.01 & 0.143 \\
\hline $25 \mathrm{~min}$ & 99 & 0.01 & 99 & 0.01 & 0.359 \\
\hline $30 \mathrm{~min}$ & 99 & 0.01 & 99 & 0.01 & 0.067 \\
\hline $35 \mathrm{~min}$ & 99 & 0.01 & 99 & 0.01 & 0.253 \\
\hline $40 \mathrm{~min}$ & 99 & 0.01 & 99 & 0.01 & 0.314 \\
\hline $50 \mathrm{~min}$ & 99 & 0.00 & 99 & 0.01 & 0.219 \\
\hline $60 \min$ & 99 & 0.00 & 99 & 0.01 & 0.187 \\
\hline $70 \mathrm{~min}$ & 99 & 0.01 & 99 & 0.01 & 0.215 \\
\hline
\end{tabular}

The comparison of $\mathrm{SpO}_{2}$ between two groups is statistically not significant ( $\mathrm{p}>0.05)$.

Table 9: Comparison of complications between two groups of patients

\begin{tabular}{|l|l|l|l|l|l|}
\hline \multirow{2}{*}{ Complications } & \multicolumn{2}{|l|}{ Group A (n=20) } & \multicolumn{2}{l|}{$\begin{array}{l}\text { Group } \\
(\mathbf{n = 2 0})\end{array}$} & $\begin{array}{l}\text { p- } \\
\text { value }\end{array}$ \\
\cline { 2 - 5 } & No & $\mathbf{\%}$ & No & \% & \\
\hline Hypotension & 3 & 15.0 & 2 & 10.0 & 0.667 \\
\hline Nausea & 1 & 4.0 & 2 & 10.0 & 0.609 \\
\hline Vomiting & 0 & - & 1 & 5.0 & 0.490 \\
\hline Sedation & 0 & - & 2 & 10 & 0.074 \\
\hline Pruritus & 0 & 0 & 0 & 0 & 0 \\
\hline Shivering & 0 & 0 & 0 & 0 & 0 \\
\hline Urinary retention & 0 & 0 & 0 & 0 & 0 \\
\hline $\begin{array}{l}\text { Respiratory } \\
\text { Depression }\end{array}$ & 0 & 0 & 0 & 0 & 0 \\
\hline
\end{tabular}

The incidence of hypotension, nausea and vomiting was comparable in both the groups. 3 patients in group B had grade 1 sedation, but none in group A, 2 patients in group B had vomiting and none in group A (statistically not significant). No postoperative complications were recorded in both groups.

\section{Discussion}

Centroneuraxis block results in a sympathetic blockade, sensory analgesia and motor blockade (depending on dose, concentration and/or volumes of a local anaesthetic) after insertion of a needle in the plane of the centroneuraxis. ${ }^{[6]}$ Spinal anaesthesia requires a small mass (i.e. size) of drug, virtually devoid of systemic pharmacological effects to produce profound, reproducible sensory analgesia and superb skeletal muscle relaxation facilitating surgical exposure.

It is clear that the low spinal anaesthesia (i.e. at T10 or lower spinal level) carries different physiological impact than does a block performed to produce high (>T5) spinal anaesthesia. Low dose spinal anaesthesia has been advocated in the interest of maintaining cardiovascular stability especially in lower abdominal and perineal surgeries. Inadequate analgesia/pain relief in the perineal region is discomforting to the patient and can cause reflex inhibition of bladder evacuation. ${ }^{[2]}$

"Saddle block" anaesthesia with low dose of local anaesthetic limits blockade to sacral fibres and carries the advantages of haemodynamic stability and minimal respiratory changes. Since perineal surgeries do not require extensive motor blockade with muscle relaxation, avoiding local anaesthetic and using intrathecal Pethidine has been associated with haemodynamic stability and early ambulation. ${ }^{[3,5]}$

A study by Acalovschi, et al, ${ }^{[5]}$ showed that saddle block with pethidine hydrochloride (5\%, preservative-free) in a dose of $0.5 \mathrm{mg} / \mathrm{kg}$ bodyweight for patients undergoing short surgical operations on the perineum was safe and provide haemodynamic stability and better postoperative analgesia. Chaudari LS et al ${ }^{[2]}$ did a comparative study of intrathecal Pethidine (preservative-free) $0.5 \mathrm{mg} / \mathrm{kg}$ body weight $\mathrm{v} / \mathrm{s} 1 \mathrm{ml}$ of 5\% lignocaine (dense) as an anaesthetic and postoperative analgesia for perineal surgeries and concluded that 
intrathecal pethidine (preservative-free) $0.5 \mathrm{mg} / \mathrm{kg}$ body weight provides excellent anaesthesia for perianal operation, though the time taken for onset of sensory and motor blockade was significantly longer than lignocaine.

Considering all these studies we decided to use intrathecal Pethidine (preservative-free) $0.5 \mathrm{mg} / \mathrm{kg}$ body weight v/s $1 \mathrm{ml}$ of $5 \%$ lignocaine as a sole anaesthetic and postoperative analgesia for perineal surgeries in our comparative study

\section{Patient characteristics}

In the present study, both groups were comparable with respect to age, sex, height and weight.

\section{Onset sensory and motor blockade}

In our study the sensory block at L1 was achieved in $2.01 \pm 1.06 \mathrm{~min}$ in group A as compared to $2.56 \pm 1.64 \mathrm{~min}$ in group B which was statistically significant $(\mathrm{p}<0.05)$

Similarly onset of grade 1 motor blockade in group A was 3.56(SD 0.88) and in group B 7.22 (SD 1.11), which was statistically significant $(\mathrm{p}<0.05)$.

The study by Acalovschi V, Ene et al, ${ }^{[5]}$ using Pethidine (preservative-free) $0.5 \mathrm{mg} / \mathrm{kg}$ body weight in saddle block achieved sensory block after $(5.28 \pm 1.43) \mathrm{min}$, similar to the findings of our study $(6.76 \pm 1.64) \mathrm{min}$.

Study by Chaudari LS et al, ${ }^{[3]}$ compared intrathecal Pethidine (preservative-free) $0.5 \mathrm{mg} / \mathrm{kg}$ body weight $\mathrm{v} / \mathrm{s} 1 \mathrm{ml}$ of $5 \%$ lignocaine intrathecally. Mean onset of sensory blockade was $6.37 \mathrm{~min}$ in pethidine group and $2.19 \mathrm{~min}$ in lignocaine group, the mean onset of motor blockade was $2.65 \mathrm{~min}$ in lignocaine group and 8.08 min in Pethidine group which was statistically significant $(\mathrm{p}<0.05)$. The findings correlate closely with the present study - sensory blockade (in group A - Lignocaine was $2.00 \pm 1.06 \mathrm{~min}$; Group B-Pethidine was $3.56 \pm 1.64 \mathrm{~min}$ ) and motor blockade was (in group A Lignocaine was 2.56 (SD 0.88) $\mathrm{min}$ and in group B Pethidine was 7.22 (SD 1.11)) min, which is statistically significant.

\section{The degree of motor blockade}

Grade 1 motor paralysis was seen in 2 cases (1\%) in group A and $15(75 \%)$ in group B which was statistically significant. Grade II motor paralysis occurred in 6(30\%) cases in A, whereas in B $5(25 \%)$. Grade III motor paralysis was noticed in 12 cases $(60 \%)$ in group A and none of the patients in group B had grade III motor paralysis and this was statistically significant. Karangale $\mathrm{K}$, Rathi $\mathrm{P}$ et al, ${ }^{[7]}$ study showed grade 0 motor paralysis in (group pethidine -2 cases and group lignocaine in 1 case). Grade I paralysis in (group pethidine - 13 cases and in group lignocaine 2 cases). Grade II paralysis in (group pethidine 11 instances and in group lignocaine 10 instances) and Grade III paralysis in (group pethidine 4 cases and 17 cases in lignocaine group).

\section{Hemodynamic parameters}

Pulse rate, systolic pressure and diastolic blood pressure were comparable in both the groups. Pulse rate in both the groups followed a similar trend with pulse rate remaining higher in group B but this was not statistically significant. The incidence of hypotension was $16 \%$ and $8 \%$ respectively in group A and group B which was not statistically significant.

Otherwise systolic pressure and diastolic blood pressure in both the groups followed a similar trend and remained stable throughout. Same results were obtained in Chaudari LS et al, ${ }^{[2]}$ study and the incidence of hypotension was $10 \%$ in lignocaine group and $4 \%$ in pethidine group was statistically not significant.

\section{Time for regression of sensory and motor blockade}

In the present study, time for neural regression at L1 was $65.12 \pm 4.83 \mathrm{~min}$ in group A and $94.60 \pm 6.88 \mathrm{~min}$ in group B, which was statistically very significant $(\mathrm{p}<0.05)$. The time for regression of motor blockade was $60.40 \pm 3.85$ in group A and $60.20 \pm 5.02$ in group $B$, respectively, which was statistically not significant ( $\mathrm{p}>0.05)$.

In a study by Chaudari LS et al, ${ }^{[3]}$ sensory blockade lasted for $97.32 \mathrm{~min}$ in pethidine group and $58.0 \mathrm{~min}$ in lignocaine group. In Mrs. K Karnagale, P Rathi et al, ${ }^{[7]}$ study (1 $\mathrm{ml}$ of preservative-free Pethidine or $50 \mathrm{mg} / \mathrm{ml}$ of $1 \mathrm{ml}$ of lignocaine for subarachnoid block) the time for regression of motor blockade was $70 \mathrm{~min}$ (range 30-120 $\mathrm{min}$ ) in pethidine group and 99 min (range 40-160 min) in lignocaine group which was statistically not significant. Comparable to the present study - the time required for motor recovery in lignocaine group is $60.40 \pm 3.85$ and is $60.35 \pm 5.02$ in pethidine group, whereas the time necessary for sensory regression in lignocaine group is $65.12 \pm 4.83$ and is $94.60 \pm 6.88$ in pethidine group.

\section{Duration of postoperative analgesia}

In the present study the duration of postoperative analgesia was $122.84 \pm 9.37 \mathrm{~min}$ in-group $\mathrm{A}$ and $320.60 \pm 23.02$, which was statistically very significant.

In Acalovschi et al, ${ }^{[5]}$ study, the duration of postoperative analgesia was $301 \pm 98.38 \mathrm{~min}$ in the pethidine group and $109 \pm 31.7$ in lignocaine group which was statistically very significant. Our results concur with this study.

\section{Complications and side effects}

In the present study we noticed drowsiness in 2 cases ingroup B and none in-group A. Nausea - 1 case (5\%) in group A and 2 cases $(10 \%)$ in-group B. Vomiting none in group A and 2 cases $(10 \%)$ in group B. Incidence of all the abovementioned complications were comparable in both the groups without having any statistical significance. None of the cases in either group had respiratory depression.

Chaudari LS et al, ${ }^{[2]}$ in their study noticed nausea in $38 \%$ of patients in the pethidine group and $12 \%$ in lignocaine group. Vomiting was seen in $22 \%$ patients in the pethidine group and $8 \%$ in the lignocaine group. Hypotension occurred in $4 \%$ in the pethidine group and $10 \%$ in the lignocaine group. Pruritus- $26 \%$ in the pethidine group and none in the lignocaine group, Urinary retention occurred in $6 \%$ of patients in the pethidine group and $30 \%$ in the lignocaine group, which was statistically not significant.

\section{Conclusion}

From the present study we conclude that intrathecal Pethidine (preservative-free) in a dose of $0.5 \mathrm{mg} / \mathrm{kg}$ is useful as a sole anaesthetic agent for patients undergoing perineal surgeries and produces prolonged postoperative analgesia without significant untoward effects or complications. 


\section{Acknowledgment}

The author thankful to Department of Anesthesiology, Pratima Medical College for providing all the facilities to carry out this work

\section{References}

1. Comparison of $5 \%$ with dextrose, $1.5 \%$ with dextrose, and $1.5 \%$ dextrose - free lidocaine solutions for spinal anaesthesia in Human volunteers. Anaesth Analg 1995; 81:697-702

2. Chaudari. Comparative study of intrathecal Pethidine versus lignocaine as an anaesthetic and a postoperative analgesia for perineal surgery. $\mathrm{J}$ Postgrad Med (serial on line) 1996; 42: 43-5.

3. Mircea $\mathrm{N}$ et al. Anaesthesia L anaesthesic sous - arachnoidienne paar la pethidine Ann fr. Anaesthetic reanim. Br J Anaesth 1982; 1: 167.

4. Paul G. Barash et al. Clinical anaesthesia. 3rd ed, 337-339.

5. Acalovschi G. Saddle block with Pethidine for perineal operations. Br J Anaesthesia 1986; 58: 1012-1010.

6. Ronald D Miller, 3rd edition, 1377-78

7. Patil BO, Sonavdekar SR, Mathur R. A Study on Effects of Dexmedetomidine Used as an Adjuvant in Epidural Post-Operative Analgesia. Asian J. Med. Res. 2019;8(3):AN01-AN04.

8. Karangale K. P. Rathi. Intrathecal Pethidine as an only anaesthetic: A comparison with lidocaine. Indian J Anaesth 1989; 37: 27.

Copyright: ( $)$ the author(s), 2020. It is an open-access article distributed under the terms of the Creative Commons Attribution License (CC BY 4.0), which permits authors to retain ownership of the copyright for their content, and allow anyone to download, reuse, reprint, modify, distribute and/or copy the content as long as the original authors and source are cited.

How to cite this article: Reddy JS. Comparative Efficacy of Intrathecal Pethidine with Lignocaine 5\% (Heavy) as Sole Anaesthetic Agent for Perineal Operations. Acad. Anesthesiol. Int. 2020;5(1):78-83.

DOI: dx.doi.org/10.21276/aan.2020.5.1.16

Source of Support: Nil, Conflict of Interest: None declared. 